of Entomology (London and Farnham Royal); Prof. A. M. Tyndall, Henry Overton Wills professor of physies in the University of Bristol; Prof. J. H. M. Wedderburn, professor of mathematics in Princeton University.

\section{Elections to the Royal Society of Edinburgh}

THE following were elected fellows of the Royal Society of Edinburgh at a meeting held on March 6 : Dr. F. L. Arnot, lecturer in natural philosophy in the University of St. Andrews; Major P. C. Banerjee, Indian Medical Service; Mr. J. L. Begg, treasurer and past vice-president of the Geological Society of Glasgow; Dr. T. R. Bolam, lecturer in chemistry, University of Edinburgh; Mr. Finlay J. Cameron, general manager, Caledonian Insurance Company, Edinburgh; Mr. J. I. Carswell, lecturer in engineering, University of Edinburgh; Dr. A. M. Clark, lecturer and director of studies, University of Edinburgh; Dr. A. L. Craig-Bennett, lecturer in zoology, University of Edinburgh; Mr. E. G. Dymond, Carnegie research fellow and lecturer in natural philosophy, University of Edinburgh; Mr. J. M. Erskine, general manager, Commercial Bank of Scotland, Ltd., Edinburgh; Dr. Thomas Ferguson, H.M. medical inspector of factories, Home Office; Prof. C. Forrester, Department of Chemistry and Assaying, and acting Principal, Indian School of Mines, Dhanbad ; Dr. W. H. Fowler, medical radiologist, Edinburgh ; Mr. A. W. de R. Galbraith, city engineer, architect and surveyor, Christchurch, New Zealand; Mr. A. C. Gardner, chief engineer, Clyde Navigation Trust, Glasgow; Dr. R. P. Gillespie, lecturer in mathematics, University of Glasgow; Mr. T. H. Gillespie, director-secretary, Zoological Society of Scotland, Edinburgh; Mr. W. G. Guthrie, assistant in applied mathematics, University of St. Andrews ; Lieut.-Col. E. E. Hume, Medical Corps, United States Army, librarian of the Army Medical Library, Washington, D.C.; Dr. D. Lees, clinical medical officer, Corporation of Edinburgh and surgeon in charge of venereal diseases, Royal Infirmary, Edinburgh; Mr. J. Macleod, manager, Glasgow Corporation Chemical Department; Prof. J. Malcolm, Department of Physiology, University of Dunedin, New Zealand; Mr. W. J. M. Menzies, inspector of salmon fisheries of Scotland, Fishery Board for Scotland, Edinburgh ; Prof. L. M. MilneThomson, assistant professor of mathematics, Royal Naval College, Greenwich; Dr. J. Murray, Rector, The Academy, Annan; Mr. T. Nicol, lecturer in anatomy, University of Glasgow ; Mr. C. W. Parsons, lecturer in zoology, University of Glasgow; Mr. A. W. N. Pillers, chief veterinary officer, Corporation of Liverpool and lecturer on veterinary parasitology, University of Liverpool Veterinary School; Mr. F. A. B. Preston, lecturer in municipal engineering, Town Planning, etc., Royal Technical College, Glasgow ; Mr. J. L. Somerville, auditor to the University of Edinburgh; Dr. J. B. Tait, junior naturalist (hydrographer), Fishery Board for Scotland, Aberdeen; Mr. G. Taylor, assistant keeper, Department of Botany, British Museum; Dr. G.
Timms, lecturer in mathematics, University of St. Andrews ; Prof. J. M. Watt, Department of Pharmacology and lecturer in dental materia medica, University of the Witwatersrand, Johannesburg; Dr. W. F. J. Whitley, medical officer of health, Northumberland County Council; Mr. J. Wright, Kirkcaldy.

\section{Centenaries of Priestley and Pepys}

THE bicentenary of the birth of Joseph Priestley occurs on March 13, and elsewhere in this issue we print articles discussing his scientific work and describing his visits to London. A few weeks ago (NATuRe, Feb. 18), reference was made to the association of Samuel Pepys with the Royal Society, the tercentenary of whose birth fell on February 23. Bicentenaries and tercentenaries of scientific interest are not of frequent occurrence and the Royal Society is marking the occasion by an "At Home" at 9 o'clock on Wednesday, March 15. With further reference to the article on Pepys Mr. Edwin Chappell, 41 Westcombe Park Road, London, S.E.3, has provided us with references showing that Pepys's birthplace was definitely in London. On this subject W. H. Whitear, in "More Pepysiana" (1927), says : "From information derived from the parish books of St. Bride's, Fleet Street, it seems to be beyond doubt that Samuel was born in his father's house in Salisbury Court". It is of interest in this connexion to give the record which appears in "Alumni Canta. brigienses" (Venn, 1924) against Pepys's name: Adm. pens. Trinity Hall, June 21, 1650. B. at Brampton, Feb. 23, 1632-3. Migrated as scholar to Magdalene, Mar. 4, 1650-1; Matric. 1651 ; B.A. 1653-4; M.A. 1660.

\section{Carsten Niebuhr, I733-1815}

ON March 17 occurs the bicentenary of the birth of the famous German traveller, Carsten Niebuhr, who was the only survivor of the Danish expedition sent to examine the monuments and antiquities of the Orient in 1761. Born in the village of Lüdingworth in the Duchy of Lauenberg, Niebuhr appeared destined to follow in the footsteps of his forbears, who were small landowners. On coming of age, however, he spent his small patrimony in obtaining instruction in mathematics and by 1757 was a student at Göttingen, where he was afterwards taught the new methods of determining longitude by lunar observations by Tobias Mayer himself. Niebuhr made great use of this method in his travels in the East which occupied the years 1761-1767. After his return to Europe he commenced the publication of the account of his travels, married and, being given an official post in the town of Meldorf in Holstein, settled there. He was made a Danish councillor of State, a knight of the Daneborg and in 1802 was elected an associate of l'Institut de France. Towards the end of his life he became blind and lame. He died at Meldorf on April 26, 1815. His son, Barthold Georg Niebuhr (1776-1831), was a distinguished historian and archæologist and his grandson, Marcus von Niebuhr (1817-1860), an eminent Prussian official. 
THE expedition which made Niebuhr famous was undertaken by the Danish Government at the instigation of the German orientalist, Johann David Michaelis (1717-1791), one of the first to study the biblical narratives as a part of Oriental history. The other members of the expedition were von Haven, a linguist, Peter Forskäl, a Swedish naturalist, Dr. Cramer, a physician, and Bauenfeind, a draughtsman. Leaving Denmark in a warship at the beginning of 1761, the party first visited Constantinople. From September 1761 until October 1762 the travellers were in Egypt, where Niebuhr determined the positions of Cairo, Rosetta and Damietta, made maps of the Nile and measured the Pyramids. Embarking at Suez, another year was spent in the Red Sea and Arabia. Most of the members, however, had been attacked with sickness; von Haven died in May 1763, Forskät in July, Bauenfeind in August and Cramer in February 1764. Niebuhr alone was left. By then he was at Bombay. About a year later Niebuhr set out on his return journey, visiting Persia, Mesopotamia and Syria, and after seeing Cyprus, Jerusalem and Damascus, he again reached Constantinople in February 1767. Three months were spent in studying the military and civil statistics of Turkey and Niebuhr then journeyed back to Denmark via Wallachia, Moldavia, Poland and Prussia. His "Descriptions of Arabia" was published in 1772 and this was followed a year or two later by his "Travels in Arabia and the Adjacent Countries". In June 1795 a fire at Copenhagen destroyed the copper-plates for the third volume and this was not published until twenty-two years after his death.

\section{Centenary of Hilary Bauerman, I833-1909}

Hilary Baufrman, who was born in London on March 16 a century ago, had an international reputation as a geologist and metallurgist. $\mathrm{He}_{\boldsymbol{\theta}}$ made geological surveys in many parts of the world, acted as juror at various international exhibitions, published widely read textbooks, and at his death left his fortune for the furtherance of the study of mineralogy. His parents, who were of German nationality, came to London in 1829. At the age of eighteen years, in 1851, Bauerman became one of the seven original students of the School of Mines in London, studying under Playfair, Ramsay, Forbes, Warington Smyth and others. He also spent three years at the Freiburg Mining Academy and then on returning to England joined the Geological Survey of Great Britain. His overseas work began with his appointment as geologist to the North American Boundary Commission. In 1868 he published his "Metallurgy of Iron", in 1883 became lecturer in metallurgy at Firth College, Sheffield, and in 1888 succeeded Prof. Percy as professor of metallurgy at the Ordnance College, Woolwich. $\mathrm{He}$ was elected an honorary member of both the Iron and Steel Institute and Institute of Mining and Metallurgy. He died unmarried at his house in Balham on December 5, 1909, and was buried in Brookwood Cemetery.

\section{Harrison's First Marine Timekeeper}

IN connexion with his efforts to make a timekeeper which would keep time accurately at sea, John Harrison made four instruments, one in $\mathbf{1 7 3 5}$, a second in 1739, a third a few years later, for which he was awarded the Copley medal of the Royal Society, and a fourth which, after being tested on a voyage to Jamaica and back lasting from November 18, 1761, until March 26, 1762, caused him to be adjudged as having won the $£ 20,000$ reward offered through the Act of Parliament of 1714. There was much delay in paying Harrison and it was laid down that all four of his time-keepers were to be handed over to the Royal Observatory. These time-keepers naturally were soon superseded by better instruments, and they ceased to be used and fell into disrepair. Some twelve years ago, however, Lieut. Comdr. Rupert T. Gould obtained permission to recondition them and he has now completed his labours by the restarting of Harrison's first marine timekeeper, made in 1735 , but not used since 1767 . All four of Harrison's instruments are thus again in working order, and according to an article in the Times of February 28, No. 1 will be kept going in an air-tight show-case. Needless to say, this instrument bears little resemblance to a modern chronometer. It weighs no less than $70 \mathrm{lb}$. Tested aboard H.M.S. Centurion and H.M.S. Orford in 1736, however, it gave satisfactory results, and on the voyage home, when the Orford sighted land the reckoning by the clock showed the position of the ship to be off the Lizard, while the ordinary methods of navigation gave the ship's position as off the Start. The former proved to be the correct position.

\section{Prof. B. Němec}

Prof. B. NÉmec, director of the Plant Physiological Institute of the Charles University, Prague, celebrates his sixtieth birthday on March 12. Prof. Němec is a well-known plant physiologist, working especially in experimental cytology and caryology, anatomy and experimental morphology, physiology of fertilisation and genetics, on symbiosis and parasitism, plant pathology, regeneration and other aspects of plant physiology. His statolith theory in plants is widely known, and also his more recent discoveries, by the use of chloral hydrate and other agents, concerning artificially induced mixoploidy and polyploidy in plants. Prof. Nðmec is well known to English scientific workers. In 1927 he lectured at University College, London, and he has attended many scientific meetings in England, the last occasion being the Fifth International Botanical Congress at Cambridge in 1930. Prof. Němec is a foreign member of the Linnean Society of London and also of many other learned societies of his own and other countries.

Sir Robert Hadfield and the Academy of Sciences of the U.S.S.R.

AT the luncheon given to Sir Robert Hadfield on February 28 by M. I. Maisky, the Soviet Ambassador in London, in honour of the election of Sir Robert 